\title{
CANCER PREVENTION: ATTITUDES AND PRACTICES AMONG BLACK SOUTH AFRICAN UNIVERSITY STUDENTS
}

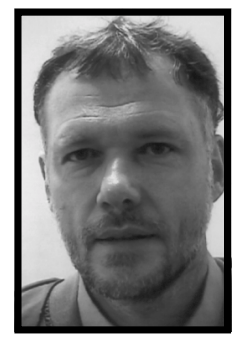

\author{
Prof. Karl Peltzer
}

Department of Psychology

University of the North

\section{ABSTRACT}

This study intended to investigate the attitudes and practices of cancer prevention among Black South African university students. The sample included 793 Black University students from non-health courses chosen at random from the University of the North, South Africa. The students were 370 (46.7\%) males and 423 (53.3\%) females between the ages of 18 to 25 years ( $M$ age 21.0 years, $S D=3.48$ ). Results indicate that $27.5 \%$ of the women said that they knew how to examine their breasts. About one third (34.2\%) of those who knew about breast self-examination never did breast self-examination and $25.5 \%$ did it the recommended 10 and more times a year. While $87.8 \%$ had never had a cervical smear test, $6.8 \%$ had at least one the previous year. Overall, $24.2 \%$ of the male students knew how to examine their testicles for cancer, and from those who knew this $41.9 \%$ had never done it and $22.1 \%$ did it the recommended 10 times and more a year. Logistic regression found that attitudes were an independent predictor for testicles self-examination but not for breast self-examination and cervical (pap) smear test. If cancer self-examination and tests are to be adopted on a wider scale, more effective promotion will be required.

\section{OPSOMMING}

Die doelwit van hierdie navorsing was om die houdings en praktyke vir die voorkoming van kanker onder swart studente aan Universiteite in Suid Afrika na te vors. Die steekproef het bestaan uit 793 swart studente van die Universiteit van die Noorde in Suid Afrika. Die studente is ewekansig toegewys uit studente wat nie geregistreer was vir ' $n$ kursus in die gesondheidswetenskappe nie. Die steekproef het bestaan uit: 370 (46.7 $\%)$ mans en 423 (53.3\%) dames in die ouderdomsgroep 18 tot 25 jaar (gemiddelde ouderdom 21.0j, standaardafwyking 3.48). Die resultate dui daarop dat $27.5 \%$ van die dames geweet het hoe om borste te ondersoek. Ongeveer een derde (34.2\%) van die dames wat weet hoe om die ondersoek te doen het dit nog nooit gedoen nie en $25.5 \%$ het dit volgens die aanbevole frekwensie van tien en meer keer per jaar gedoen. Sowat $87.8 \%$ het nog nooit ' $n$ papsmeer ondergaan nie en $6.8 \%$ het ten minste een die vorige jaar ondergaan. Oor die algemeen het $24.2 \%$ van die mans geweet hoe om hul testikels te ondersoek vir kanker en van die wat weet het $41.9 \%$ nog nooit die toets ondergaan nie. Sowat $22.1 \%$ het die toets volgens die aanbevole tien en meer keer per jaar gedoen. Logistieke regressie bevind dat houdings is ' $n$ onafhanklike voorspeller vir testikel selftoets maar nie vir selftoets van borste en papsmeer nie. Om die selftoets vir kanker op ' $n$ meer algemene skaal aanvaarbaar te maak, moet meer effektiewe bekendstelling gedoen word. 


\section{INTRODUCTION}

Cervical cancer is the most common form of malignancy that affects women in virtually all developing countries. It is also a leading cause of death among women in developing countries where it may account for up to $80 \%$ of all gynaecology cancers (Rogo, Omany, Onyango, Ojwang \& Stendahl, 1990:249).

In South Africa, the age adjusted burden of cancer in the African population is much less than that in the local White population, and than that in western populations. However, transitional and environmental changes have been taking place. Although the common cancers of oesophagus and liver are decreasing, those of breast, prostate, cervix and lung are rising (Sitas, Blaauw, Terblanche, Madhoo \& Carrara, 1997:12ff.). Breast cancer is the second most common cancer among South African females. A total of 3324 breast cancers were recorded in females, comprising $15.6 \%$ of all cancers in this group (ASIR 26.60/100000). The incidence was highest for White females (ASIR 58.8/100000) and lowest for Black females (ASIR 14.4/100000). Sexual and reproductive risk factors for this cancer include late age at first birth and nulliparity and probably prolonged use of oral contraceptives in young women. The incidence of cervical cancer, especially in South African Black females, is among the highest in the world. In Black females a total of 2783 cases were recorded, comprising $32.7 \%$ of all cancers seen in this group (ASIR=39,28/100000). In 1988, 1 in 21 Black females had a lifetime risk (0-74 years) of developing cancer of the cervix. It is now well established that cancer of the cervix is a sexually transmitted disease. Risk factors for cervical cancer include early age at first intercourse and multiple sexual partners (Sitas \& Norman, 1995:149ff.). Testicular tumours are the most common form of malignant disease in men aged 25-34 years (Davison, Cumming, Swainson \& Turner, 1999:470).
In developed countries $80 \%$ of cervical cancer cases are in the early stages and curable. However, in developing countries $80 \%$ of cervical cancer cases are incurable at the time of detection, if they are detected at all (WHO, 1996:346). Reports from developed countries have shown routine screening to be effective in reducing morbidity and mortality from cervical cancer (Ajayi \& Adewole, 1998:42). Although regular breast self-examination may reduce breast cancer mortality, the majority of women do not practice it (Salazar, 1994:49). Katz, Meyers and Walls (1995:377) found among College students in USA that both men and women were poorly informed about cancer risk factors, warning signs and self-examination practices for testicular cancer and breast cancer.

Breast self-examination is recommended for the early detection of breast cancer in the European Code against Cancer and by the Cancer Association of South Africa. Early detection of breast, cervical and testicular cancer can reduce cancer mortality. Testicular self-examination is also recommended for the early detection of testicular cancer (Cancer Association of South Africa, 2000; Wardle, Steptoe, Smith, Groll-Knapp, Koller, Smith \& Brodziak, 1995:61; Wardle, Steptoe, Burckhardt et al. 1994:206).

Research into the social and psychological predictors of preventive health behaviours has consistently found that attitudes towards the behaviour are significantly associated with compliance (Janz \& Becker, 1984:1). Investigations of cancer self-examination practice have found similar results, with attitudes towards breast selfexamination, particularly belief in it's benefits or efficacy, being strongly associated with breast selfexamination frequency (Walker \& Glanz, 1986:169; Wardle et al. 1995:61; Wardle et al. 1994:296). Although some studies have investigated knowledge and attitudes towards cancer among African populations (Walker, Walker, Jerling, Rossouw \& Lelake, 1999:80; Orret, Balbirsing \& 
Pinto-Pereira, 1996:400), no study could be found on the actual cancer preventive practices. The data of the present study permitted the evaluation of the association between cancer self-examination attitudes and cancer self-examination practice.

The aims of the study were to evaluate the attitudes, knowledge and preventive practices of breast selfexamination and cervical smear test among young Black South Africa women and the attitudes, knowledge and preventive practices of testicle selfexamination among young Black South African men, and to establish a predictive value between the preventive practice and attitudes.

\section{METHODS}

\section{Sampling}

The sample included 793 Black University students from non-health courses chosen from randomly selected classes from the University of the North, South Africa. The students were 370 (46.7\%) males and $423(53.3 \%)$ females between the ages of 18 to 25 years ( $M$ age 21.0 years, $S D=3.48$ ). Twenty-four percent of the students studied in the Faculty of Mathematics and Natural Sciences, $46.9 \%$ in Management Sciences, and $28.4 \%$ in Arts and Social Sciences. Most came from a not very welloff $(45.5 \%)$ or quite poor $(24.1 \%)$ academic background.

\section{Data collection}

Data were collected by a self-administered questionnaire in a class room situation after informed consent had been obtained. Participants were assured of complete anonymity.

\section{Breast self-examination and cervical (pap) smear practice}

Women were asked whether they knew how to examine their breasts for lumps (Yes/No) and if so, how often they examine them. Response options were never, 1 to 2 times per year, 3 to 10 times per year and more than 10 times per year. This last category was considered to represent adequate compliance with a monthly breast self-examination recommendation (Wardle, Steptoe, Smith et al. 1995: 62f.). Women were further asked how long it has been since they had a cervical (pap) smear test, and the reponse options were never, less than one year, 1 to 3 years, and more than 3 years.

\section{Breast self-examination and cervical smear test attitude}

This was indexed by a single question on attitude to breast self-examination (how important to health is it for women to examine their breasts at least once a month for possible signs of cancer?), and a single question on attitude to cervical smear test (how important to health is it for women to have a regular cervical smear test?). Both questions were scored from 1 (not at all important) to 10 (very important) (Wardle et al. 1995:62f.).

\section{Testicle self-examination practice and attitude}

Men were asked whether they knew how to examine their testicles for lumps (Yes/No) and if so, how often they examine them. Response options were never, 1 to 2 times per year, 3 to 10 times per year and more than 10 times per year. This last category was considered to represent adequate compliance with a monthly testicle self-examination recommendation.

This was indexed by a single question on attitude to testicle self-examination (how important to health is it for men to examine their testicles at least once a month for possible signs of cancer?). The question was scored from 1 (not at all important) to 10 (very important) (pers. com. Prof. Steptoe, 14 September 1999).

Cronbach alpha as well as split-half reliability coefficients for the 'cancer scale' was .72 and .89 for this sample. 


\section{Data analysis}

Descriptive statistics and regression analyses was used to analyse the data with the SPSS (version 8).

\section{RESULTS}

Knowledge and practice of breast selfexamination and cervical (pap) smear test

Overall, $27.5 \%$ of the women students said that they know how to examine their breasts.

The breast self-examination frequency who knew how to examine their breasts and the frequency of pap smear tests are shown in Table1. About one third (34.2\%) of those who knew about breast selfexamination never did breast self-examination and
In relation to the importance of health benefits of breast self-examination, cervical (Pap) smear, and testicles self-examination women had a mean rating of $6.4(\mathrm{SD}=3.9)$ for breast self-examination and 5.9 $(\mathrm{SD}=3.9)$ for cervical (pap) smear and men had a mean rating of $6.2(\mathrm{SD}=3.9)$ for testicle selfexamination.

The predictive value of attitudes to breast selfexamination, attitudes to cervical (pap) smear, and attitudes to testicles self-examination was evaluated by logistic regression. For this analysis, breast selfexamination, cervical (pap) smear and testicles selfexamination were coded as never (0) or ever (1). Results revealed that attitudes were an independent predictor for testicles self-examination (Wald $=8.80$, $\mathrm{p}<.003, \mathrm{r}=.19$, Odds Ratio $=1.18$ ) but not for breast

Table 1: Frequency of breast self-examination and pap smear tests by women in percent

\begin{tabular}{|l|l|l|l|}
\hline Breast self-examination & Percent & $\begin{array}{l}\text { Duration since last } \\
\text { cervical (pap) } \\
\text { smear test }\end{array}$ & \\
\hline Never (\%) & 34.2 & Never (\%) & 87.8 \\
\hline $1-2$ times a year & 28.0 & $<1$ year & 6.8 \\
\hline $3-10$ times a year & 2.5 & $1-3$ years & 4.2 \\
\hline More than 10 times a year & 25.5 & $>3$ years & 1.2 \\
\hline
\end{tabular}

$87.8 \%$ had never had a cervical smear test.

Knowledge and practice of testicles selfexamination for cancer (lumps)

Overall, $24.2 \%$ of the male students knew how to examine their testicles for cancer. From those who knew how to examine their testicles for cancer $41.9 \%$ had never done it, $14 \% 1$-2 times, $22.1 \% 3$ 4 times, and $22.1 \%$ the recommended more than 10 times.

\section{Attitudes to breast self-examination, cervical (pap) smear and testicles self-examination}

self-examination and cervical (Pap) smear test.

\section{DISCUSSION}

The low levels of breast self-examination identified in this study are disturbing in view of the fact that the recommendation of the South African Cancer Association for Breast Self-Examination is monthly after the age of 18, 7 days after the period stops, and for Testicular Self-Examination monthly after the age of puberty (pers. com. Cancer Association, South Africa, 14 August 2000). Among European University students $54 \%$ of the women reported as never having practiced breast self-examination, $8 \%$ 
monthly, and 36\% reporting regular breast selfexamination (Wardle et al. 1995:61). Budden (1995:23) found among 17-45 year old American College women that $99 \%$ had performed breast selfexamination in the previous 12 months, though fewer than half rated it as regular.

Only $24.2 \%$ of the male students knew how to examine their testicles for cancer. Regular practice (monthly) was reported by only $5.3 \%$ of the sample, with another $8.7 \%$ reporting occasional testicular self-examination. This finding is similar to what Wardle et al. (1994) found among male university students in Europe, namely 3\% regular and 10\% occasional testicular self-examination. Wardle et al. (1994) also found, as in this study, that attitude toward testicular self-examination among men was a significant predictor of testicular self-examination practice.

\section{CONCLUSION}

Both the low levels of attitudes, knowledge and preventive practices of cancer self-examination and the low ratings of the importance of cancer selfexamination practice suggest that young women and men in South Africa are unaware of the value of this method of early detection of cancer. If cancer self-examination and tests are to be adopted on a wider scale, more effective promotion will be required.

Knowledge deficiencies and low preventive selfexamination practices for testicular cancer, breast cancer and cervical cancer among young Black South Africans need to be addressed such as in a national pap smear screening programme to reduce the incidence of cancer of the cervix as suggested by Sitas and Norman (1995:156).

If cancer self-examination is to continue to be promoted as part of the cancer prevention effort in South Africa, then it would appear to be vital to improve the succes of cancer self-examination advice in influencing behaviour as well as attitudes (cf. Wardle et al. 1995:67).

Further research on early detection, selfexamination and prevention of cancer in South Africa is required (Schlebusch, 1998:4-6; Sitas \& Norman, 1995:156f.).

\section{Acknowledgement}

This research was supported by a grant by the University of the North.

\section{REFERENCES}

Ajayi, IO \& Adewole, IF 1998: Knowledge and attitude of general outpatient attendants in Nigeria to cervical cancer. Central African Journal of Medicine, 44:4143.

Budden, L 1995: Young women's breast self-examination knowledge and practice. Journal of Community Health Nursing, 12:23-32.

Cancer Association of South Africa, 2000: Personal communication, August 2000.

Davison, AA; Cumming, AD; Swainson, CP \& Turner, N 1999: Diseases of the kidney and urinary system. (In: C Haslett; ER Chilvers; JAA Hunter \& NA Boon eds. Davidson's principles and practice of medicine. Edinburgh: Churchill Livingstone. pp. 417-470).

Janz, NK \& Becker, MH 1984: The health belief model: a decade later. Health Education Quarterly, 11:1-47.

Katz, RC; Meyers, K \& Walls, J 1995: Cancer awareness and self-examination practices in young men and women. Journal of Behavioral Medicine, 18:377-384.

Orret, FA; Balbirsing, M \& Pinto-Pereira, LM 1996: Knowledge of cervical cancer in teenage school children in Trinidad. East African Medical Journal; 73:400403. 
Rogo, KO; Omany, J; Onyango, JN; Ojwang, SB \& Stendahl, U 1990: Carcinoma of the cervix in an African setting. International Journal Obstetrics \& Gynaecology, 33:249-255.

Salazar, MK 1994: Breast self-examination beliefs: a descriptive study. Public Health Nursing, 11:49-56.

Schlebush, L ed. 1998: Psycho-oncology and behavioural medicine: a programme for priority research in South Africa. Johannesburg: The Cancer Association of South Africa.

Sitas, F \& Norman, RP 1995: Lifestyle-induced cancers. (In: J Furie \& K Steyn eds. Chronic diseases of life style in South Africa. Cape Town: MRC Technical Reports. pp. 147-160).

Sitas, F; Blaauw, D; Terblanche, M; Madhoo, J \& Carrara, H 1997: Cancer in South Africa. Johannesburg: South African Institute for Medical Research.

Walker, LR \& Glanz, K 1986: Psychosocial determinants of breast self-examination. American Journal of Preventive Medicine, 2:169-178.

Walker, ARP; Walker, BF; Jerling, J; Rossouw, K \& Lelake, A 1999: Health and cancer prevention: implications of the knowledge and beliefs of 15-16 year old school pupils in South Africa. The Journal of the Royal Society for the Promotion of Health, 119:8084.

Wardle, J; Steptoe, A; Smith, H; Groll-Knapp, E; Koller, M; Smith, D \& Brodziak, A 1995: Breast selfexamination: attitudes and practices among young women in Europe. European Journal of Cancer Prevention, 4:61-68.

Wardle, J; Steptoe, A; Burckhardt, R; Voegele, C et al. 1994: Testicular self-examination: attitudes and practices among young men in Europe. Preventive Medicine, 23:206-210.
WHO 1996: Cervical cancer control in developing countries. Bulletin of the WHO, 74:345-351. 